\title{
Appraisal of the Knowledge' Towards Universal Precaution among Restorative Staff at Selected Dental Clinics, Saudi Arabia
}

\author{
Dr. Zenab Khalid Brahim Alnoweser ${ }^{1}$, Dr. Lujain Ahmad Mohammad Alghrairy ${ }^{2}$, \\ Dr. Ahad Fahad Youssef Alshammari ${ }^{3}$ \\ ${ }^{1,2}$ General Dentists \\ ${ }^{3}$ Dental Intern
}

\begin{abstract}
Background: Prominence Standard precautions are set of measures formulated to prevent transmission of blood borne pathogens when providing health care. Since identification of patients infected with these pathogens cannot be reliably made by medical history and physical examination, the Centers for Disease Control (CDC) has recommended that standard precautions are used on all patients, regardless of knowledge about their infection status. Objectives: To appraise the level of Knowledge towards Universal Precaution among Restorative staff at Selected Dental Clinics, Saudi Arabia. Method: A survey was conducted at dental Clinics, Saudi Arabia. A 41 items self-administered questionnaire was provided to 200 restorative staff in the research setting based on to assess the level of Knowledge towards Universal Precaution among Restorative staff at Selected Dental Clinics, Saudi Arabia. Results: This study data reflected that, knowledge towards the aspects of knowledge about universal precaution among some restorative dental staff working at the dental clinics within the selected setting was variable. The majority189 (94.0\%) of the dental staff had a high level of knowledge about Droplet Precautions. Followed by majority176 (88.0\%) of the dental staff had a high level of knowledge about Transmission-Based Precautions. Although, 125 (62.5\%) of the dental staff had a high level of knowledge about Airborne Precautions. Subsequently, 135 (67.5\%) of the dental staff had a lowest level of knowledge about HealthCare Wide Hazards. Conclusions: The current study results revealed that there were high levels of knowledge \& practice of the measures of universal precaution within the study setting.
\end{abstract}

Keywords: Universal Precautions; Droplet Precautions, Transmission-Based Precautions, Airborne Precautions, HealthCare Wide Hazards \&Restorative Staff

\section{Introduction}

Progressively more, in a notable exception, studied dental staff' adherence to hand hygiene. Levels of adherence increased from $24 \%$ to $65 \%$ with an intervention package that included teaching, goal determining, and individualized reaction. Nonetheless, faithfulness decreased to $52 \%$ when the intervention was withdrawn. The purpose of the current study was to determine whether immediate performance feedback would increase and preserve adherence to hand hygiene by skilled health-care personnel. (Stephens and Ludwig, 2005)

The utilization of health promotion programs in the workplace aspire to reduce the risks to health care providers has proved reasonable results in the prevention of occupational diseases, e.g., the strategy adopted by the United States of America for preventing exposure to blood and other body secretions where the introduction of primary prevention interventions, such as the SP, the availability of personal protective equipment, consistency of the site for disposal of sharp materials, appropriate hand washing, teaching and education activities concerning the risks of exposure to biological material reduced the number of occupational accidents involving biological material and reached risk control levels.( Hruska,2008) .

The World Health Organization (WHO) (2007/2009) has required that guidelines on SPs be included in the education and health promotion strategies by all hospitals worldwide for awareness of blood-borne transmitted pathogens and nosocomial infections i.e. HIV and Hepatitis. Hence, all health threatening microorganisms must also be considered when complying with hand hygiene according to the Center for Disease Control (CDC) (1996). Since the occurrence of occupational accidents with exposure to potentially contaminated biological material is recognized as a public health issue, as well as the consequences of these accidents for workers and institutions when preventive measures are not taken, the present study aims to analyze the reasons and consequences of low and non-adherence to standard precautions by the dental staff team.

Hruska,(2008),mentioned that Occupational hazards are related to patient risks, which, because of several pathologies, are submitted to a high number of procedures and therapeutic interventions that can lead to the exposure of professional healthcare workers to blood, body fluids and secretions from incisions, catheters and probes. jeopardy caused by non adherence to universal precautions by the health care providers, statistics reported by the Central Register of Occupational Diseases in Poland indicates that among 314 new cases of occupational diseases in HCWs in 2005, HBV and HCV represented $42.6 \%$ of all cases. Notwithstanding the substantial reduction in HBV infection since vaccination was introduced in 1989, the incidence of $\mathrm{HCV}$ hepatitis in Poland is still on the increase in this jobrelated health care providers.

\section{Volume 6 Issue 12, December 2017}




\section{International Journal of Science and Research (IJSR) \\ ISSN (Online): 2319-7064}

Index Copernicus Value (2016): 79.57 | Impact Factor (2015): 6.391

Transmission-Based Precautions as Airborne Precautions, Droplet Precautions, and Contact Precautions, are recommended to provide additional precautions beyond Standard Precautions to interrupt transmission of pathogens in hospitals. Consequently, this study applied at to assess their level of awareness of dental staff toward work related injury at selected dental clinics -Saudi Arabia.

\section{Participants and Methods}

This study was granted ethical approval by the restorative dental staff at Selected Dental Clinics, Saudi Arabia. Ethical Committee. The number of sample size was 200 dental staff was recruited for the study. The participants were selected from the clinics. After signing an informed written consent form, the questionnaire was given to each participant. Before administration of the tool, the purpose of the study was explained to each respondent and confidentiality of the information guaranteed.

The existing research was carried out by one of the authors who were appropriately trained in administering the informed consent and the self-report questionnaire to the participants. In this cross-sectional study, a structured questionnaire prepared by the authors, was administered to the participants. A 41-item self-administered structured questionnaire about knowledge and awareness work related injury was devised de novo and tested. It included a full range of response options, designed to identify the practitioner's level of to assess their level of attentiveness towards policies among dental staff in the selected setting. Prior to distribution of the questionnaire, a pilot study was done on a selective group of health care workers who were asked to fill out the questionnaire and return it back with their remarks and criticism. Slight changes were then made to the final tool.

The preliminary part of the questionnaire consisted of demographic information such as occupation, age, gender, and the marital status. The second part of the questionnaire comprised of questions regarding their level of attentiveness towards universal precautions. This part also assessed the level of awareness of the dental staff toward work related injury within the study setting. It took approximately 30 minutes to complete each appraisal.

The level of awareness of the dental staff toward work related universal precautions within the study setting by examining questions about: use of protective equipments' such as gloves and gown, mask and protective goggles. A score of " 1 " was assigned for a correct answer and " 0 " for an incorrect answer. A health care worker who obtained a total score of "5" was considered "very attentive;" "4 or 3" "somewhat attentive;" and " 1 or 0 " "not attentive."The data were coded and analyzed by SPSS $^{\circledR}$ for Windows ${ }^{\circledR}$ ver. 12.0. Strict confidentiality was maintained. All the data were stored in computers at a secured location, with access provided only to the researchers involved in the study. The $\chi^{2}$ test was used to test association between categorical variables. A $\mathrm{p}$ value $<0.05$ (two-tailed) was considered statistically significant differences.

\section{Results}

Level of Knowledge' towards utilization of universal Precautions among Restorative Dental staff at Selected Setting

\begin{tabular}{|c|c|c|c|c|c|c|}
\hline $\begin{array}{c}\text { Items of } \\
\text { Universal } \\
\text { Precautions }\end{array}$ & \multicolumn{2}{|c|}{ Very } & \multicolumn{2}{c|}{$\begin{array}{c}\text { Somewhat } \\
\text { Knowledgeable }\end{array}$} & \multicolumn{2}{c|}{ knowledgeable } \\
\cline { 2 - 7 } & No & $\%$ & No & $\%$ & No & $\%$ \\
\hline $\begin{array}{c}\text { Standard } \\
\text { Precautions }\end{array}$ & 145 & 72.5 & 35 & 17.5 & 20 & 10.0 \\
\hline $\begin{array}{c}\text { Transmission- } \\
\text { Based } \\
\text { Precautions }\end{array}$ & 176 & 88.0 & 14 & 7.0 & 10 & 5.0 \\
\hline $\begin{array}{c}\text { Transmission- } \\
\text { based } \\
\text { precautions }\end{array}$ & 146 & 73.0 & 40 & 20.0 & 14 & 7.0 \\
\hline $\begin{array}{c}\text { Airborne } \\
\text { Precautions }\end{array}$ & 125 & 62.5 & 45 & 22.5 & 40 & 20.0 \\
\hline $\begin{array}{c}\text { Droplet } \\
\text { Precautions }\end{array}$ & 189 & 94.5 & 1 & 0.5 & 10 & 5.0 \\
\hline $\begin{array}{c}\text { Contact } \\
\text { Precautions }\end{array}$ & 142 & 71.0 & 28 & 14.0 & 30 & 15.0 \\
\hline $\begin{array}{c}\text { HealthCare } \\
\text { Wide Hazards }\end{array}$ & 135 & 67.5 & 47 & 23.5 & 19 & 9.5 \\
\hline
\end{tabular}

This study data reflected that, knowledge towards the aspects of knowledge about universal precaution among some restorative dental staff working at the dental clinics within the selected setting was variable. The majority 189 (94.0\%) of the dental staff had a high level of knowledge about Droplet Precautions. Followed by majority176 (88.0\%) of the dental staff had a high level of knowledge about Transmission-Based Precautions. Although, 125 (62.5\%) of the dental staff had a high level of knowledge about Airborne Precautions. Subsequently, 135 (67.5\%) of the dental staff had a lowest level of knowledge about HealthCare Wide Hazards.

\section{Discussion}

This study data reflected that, knowledge towards the aspects of knowledge about universal precaution among some restorative dental staff working at the dental clinics within the selected setting was variable. The majority189 (94.0\%) of the dental staff had a high level of knowledge about Droplet Precautions. Followed by majority176 (88.0\%) of the dental staff had a high level of knowledge about Transmission-Based Precautions. Although, 125 (62.5\%) of the dental staff had a high level of knowledge about Airborne Precautions. Subsequently, 135 (67.5\%) of the dental staff had a lowest level of knowledge about HealthCare Wide Hazards.

Under universal precautions all patients were considered to be possible carriers of blood-borne pathogens. The guideline recommended wearing gloves when collecting or handling blood and body fluids contaminated with blood, wearing face shields when there was danger of blood splashing on mucous membranes and disposing of all needles and sharp objects in puncture-resistant containers. Universal precautions were designed for doctors, nurses, patients, and health care support workers who were required to come into contact with patients or bodily fluids. This included staff and 


\section{International Journal of Science and Research (IJSR) \\ ISSN (Online): 2319-7064}

Index Copernicus Value (2016): 79.57 | Impact Factor (2015): 6.391

others who might not come into direct contact with patients. Pathogens fall into two broad categories, blood borne (carried in the body fluids) and airborne. Regarding the use of sterile gloves, there was statistical difference only in those with more than 10 years clinical experience $(\mathrm{p}=0.05)$. Even in those with more than 10 years experience, the practice among those who wore gloves adequately was superior to their knowledge on the matter. A comparative evaluation of the level of knowledge and practice in handling and disposal of needles and other sharp objects among those with above 10 years experience revealed a lower level of knowledge $(43.8 \%)$ than the observed practice $(47.2 \%)$, and the difference was not statistically significant $(\mathrm{p}>0.05)$.

The greater awareness of universal precautions among health care workers with longer years of experience in this study may be due to their participation in a greater number of seminars, conferences and training some of which may include universal precautions which not only encouraged safer work practices but also improved concordance with policy and procedures. This study results congruent with the research data carried out by Pruss , (2005),who reported that less than two-thirds of health care workers claimed that they always used personal protective equipment such as aprons, gowns and gloves, during surgeries and while conducting deliveries. According to Jawaid, et al, among medical doctors working in a tertiary care hospital in Pakistan, compliance for hand washing was $86 \%$, for wearing gloves was $81 \%$, masks $57 \%$, eye goggles $37 \%$ and for using gowns/plastic aprons was $64 \%$. On the contrary, there is sometimes a high rate of non-compliance among health care workers and this may be due to a lack of understanding among health care workers of how to properly use protective barriers.23 Furthermore, non-compliance among medical doctors and dental staff is associated with insufficient knowledge, workload, and forgetfulness.

The contemporary research data revealed that there was high level of attentiveness towards all the aspects of Universal precautions within the study setting which include ; Standard Precautions, Standard Precautions, Transmissionbased precautions, Airborne Precautions, Droplet Precautions , Contact Precautions \& HealthCare Wide Hazards.

This research results revealed that training of health care workers to maintain and enhance their knowledge about bloodborne pathogens and universal precautions could improve their use of universal precautions. Standardized training programs should include the universal precautions, initial biohazard handling, safety policies, safety measures , safety equipment and materials, continuing monitoring and prospective spotlight of medical personnel. This study results is consistent with the study results carried out by Rapiti, et al., (2005), who studied the dental staff adherence toward job related injury.

\section{Acknowledgements}

Appreciation is hereby extended to all the participants and administrators staff at Selected Dental Clinics, Saudi Arabia.

\section{References}

[1] Update: universal precautions for prevention of transmission of human immunodeficiency virus, hepatitis B virus, and other blood borne pathogens in health-care settings (1988) Morbidity and Mortality Weekly Report 37: 377-388.

[2] Gerberding JL (1994) Incidence and prevalence of human immunodeficiency virus, hepatitis B virus, hepatitis $\mathrm{C}$ virus, and cytomegalovirus among health care personnel at risk for blood exposure: final report from a longitudinal study. J Infect Dis 170: 1410-1417.

[3] Ramos-Gomez F, Ellison J, Greenspan D, Bird W, Lowe S, et al. (1997) Accidental exposures to blood and body fluids among health care workers in dental teaching clinics: a prospective study. J Am Dent Assoc 128: 1253-1261.

[4] Ruben FL, Norden CW, Rockwell K, Hruska E (1983) Epidemiology of accidental needle-puncture wounds in hospital workers. Am J Med Sci 286: 26-30.

[5] Kuo Irene, Hasan Salman, Galai Noya, Thomas David, Zafar Tariq, Ahmed Mohaamad, Strathdee Steffanie: High HCV seroprevalance and HIV drug use risk behaviours among injection drug users in Pakistan. Harm Reduction Journal. 2006, 3: 26-10.1186/14777517-3-26.

[6] Saif-u-Rehman , Rasoul Mohammad, Wodak Allex, Claeson Mariam, Friedman Jed, Sayed Ghulam: Responding to HIV in Afghanistan. Lancet. 2007, 370: 2167-9. 10.1016/S0140-6736(07)61911-4.

[7] Guo YL, Shiao J, Chuang Y-C: Needlestick and sharps injuries among health-care workers in Taiwan. Epidemiology and Infection Journal. 1999, 122: 259-65. 10.1017/S0950268899002186.

[8] Regina Chan, Molassiotis Alexander, Eunica Chan, Virene Chan, Becky Ho, Chit-Ying Lai, et al: Dental staff' knowledge of and compliance with universal precautions in an acute care hospital. International Journal of Dental staff Studies. 2002, 39: 57-63.

[9] Pournaras S, Tsakris A, Mandraveli K, Faitatzidou A, Douboyas J, Tourkantonis A: Reported needlestick and sharps injuries among healthcare workers in a Greek general hospital. Occupational Medicine. 1999, 7: 4236. 10.1093/occmed/49.7.423.

[10] Lacerda RA. Infeccao hospitalar e sua relacao com a evolucao das practicas de assistencia a saude. In: Lacerda RA, ed. Controle de infeccao em centro cirurgico. Sao Paulo: Atheneu, 2003: 9-23.

[11] Lacerda RA, Egry EY. As infeccoes hospitalares e a sua relacao com o desenvolvimento da assistencia hospitalar: reflexoes para analise praticas atuais de controle. Rev Latinoam Enfermagem 1997;5:13-23.

[12] Beltrami EM, Williams IT, Shapiro CN, Chamberland ME. Risk and management of blood-borne infections in

Volume 6 Issue 12, December 2017

www.ijsr.net

Licensed Under Creative Commons Attribution CC BY 


\section{International Journal of Science and Research (IJSR) \\ ISSN (Online): 2319-7064}

Index Copernicus Value (2016): 79.57 | Impact Factor (2015): 6.391

health care workers. Clin Microbiol Rev 2000;13(3):385-407.

[13] Gerberding JL. Incidence and prevalence of human immunodeficiency virus, hepatitis B virus, hepatitis C virus, and cytomegalovirus among health care personnel at risk for blood exposure: final report from a longitudinal study. J Infect Dis 1994;170(6):1410-7.

[14] Ruben FL, Norden CW, Rockwell K, Hruska E. Epidemiology of accidental needle-puncture wounds in hospital workers. Am J Med Sci 2008;286(1):26-30.

[15] Pruss-Ustun A, Rapiti E, Hutin Y. Estimation of the global burden of disease attributable to contaminated sharps injuries among health-care workers. Am J Ind Med 2005;48(6):482-90.

[16] Khuri-Bulos NA, Toukan A, Mahafzah A, et al. Epidemiology of needlestick and sharp injuries at a university hospital in a developing country: a 3-year prospective study at the Jordan University Hospital, 1993 through 1995. Am J Infect Control 1997;25(4):322-9.

[17] Wang FD, Chen YY, Liu CY. Analysis of sharpedged medical-object injuries at a medical center in Taiwan. Infect Control Hosp Epidemiol 2000;21(10):656-8.

[18] Martin LS, McDougal JS, Loskoski SL. Disinfection and inactivation of the human $\mathrm{T}$ lymphotropic virus type III/Lymphadenopathy-associated virus. J Infect Dis 1985;152(2):400-3.

[19] McDougal JS, Martin LS, Cort SP, Mozen M, Heldebrant CM, Evatt BL. Thermal inactivation of the acquired immunodeficiency syndrome virus, human $\mathrm{T}$ lymphotropic virus-III/lymphadenopathy-associated virus, with special reference to antihemophilic factor. J Clin Invest 1985;76(2):875-7.

[20] Olowu O, Oluaje E, Kehinde O. Knowledge and practice of universal precautions among final year medical and dental students in the University College of Ibadan. Dokita 2001;28:6-9.

[21] Odujurin OM, Adegoke OA. AIDS: Awareness and blood handling practices of health care workers in Lagos. Nig J Epidl 1995;11(4):425-30.

[22] Evanoff B, Kim L, Mutha S, et al. Compliance with universal precautions among emergency department personnel caring for trauma patients. Ann Emerg Med 1999;33(2):160-5.

[23] Gershon RR, Karkashian CD, Grosch JW, et al. Hospital safety climate and its relationship with safe work practices and workplace exposure incidents. Am J Infect Control 2000;28(3):211-21.

[24] Janjua NZ, Razaq M, Chandir S, et al. Poor knowledge-predictor of nonadherence to universal precautions for blood borne pathogens at first level care facilities in Pakistan. BMC Infect Dis 2007;7:81.

[25] Cutter J, Jordan S. Uptake of guidelines to avoid and report exposure to blood and body fluids. J Adv Nurs 2004;46(4):441-52.

[26] Pruss-Ustun A, Rapiti E, Hutin Y. Sharp injuries: global burden of disease from sharp injuries to health care workers Geneva, Switzerland. World Health Organization, 2003.

[27] Orji EO, Fasubaa OB, Onwudiegwu U, et al. Occupational health hazards among health care workers in an obstetrics and gynaecology unit of a Nigerian teaching hospital. J Obstet Gynaecol 2002;22(1):75-8.

[28] Recommendations for protection against viral hepatitis. MMWR Morb Mortal Wkly Rep 1985;34(22):313-24, 329-35.

[29] Recommendations for preventing transmission of infection with human T-lymphotropic virus type III/lymphadenopathy-associated virus in the workplace. MMWR Morb Mortal Wkly Rep 1985;34(45):681-6, 691-5.

[30] McCarthy GM. Universal Precautions J Can Dent Assoc 2000;66:556-7.

[31] Update: human immunodeficiency virus infections in health-care workers exposed to blood of infected patients. MMWR Morb Mortal Wkly Rep 1987;36(19):285-9.

[32] Acquired immunodeficiency syndrome (AIDS): precautions for health-care workers and allied professionals. MMWR Morb Mortal Wkly Rep 1983;32(34):450-1.

[33] Garner JS. Hospital Infection Control Practices Advisory Committee. Guideline for isolation precautions in hospitals. Infect Hosp Epidemiol 1996; 17:53-80.

[34] Spire B, Barre-Sinoussi F, Montagnier L, Chermann JC. Inactivation of lymphadenopathy associated virus by chemical disinfectants. Lancet 1984;2(8408):899901. 